\title{
How do public libraries function as meeting places?
}

Svanhild Aab $\varnothing^{\mathrm{a}}$, ${ }^{\text {Ragnar Audunson }}{ }^{\mathrm{a}}$, and Andreas Vårheim ${ }^{\mathrm{b}}$

${ }^{\mathrm{a}}$ Faculty of Journalism, Library and Information Science, Oslo University College, Oslo, PO 4 St.Olavs plass, N-0130 Oslo, Norway

${ }^{\mathrm{b}}$ Faculty of Humanities, University of Troms $\varnothing$, N-9037 Troms $\varnothing$, Norway

*Corresponding author

Published as: Aabø, S., Audunson, R. \& Vårheim, A. (2010). How do public libraries function as meeting places? Library \& Information Science Research 32 (1), 16-26. 


\title{
How do public libraries function as meeting places?
}

\begin{abstract}
How are libraries used as meeting places, and by whom? Through survey data, six categories of places are identified: the library as a "square," as a place for meeting diverse people, as a public sphere, as a place for joint activities with friends and colleagues, a metameeting place, and as a place for virtual meetings. Representative samples of the population in three townships in Oslo, each with a markedly different demographic profile, are surveyed. Multivariate regression analyses are performed to analyze why some people use the library for a range of meetings and others do not, as well as to examine variations in the use of the library for different kinds of meetings. Public libraries are shown to be used for a variety of meetings. Community involvement is more important than township and demographic variables in explaining variations in use of the library as a meeting place. Correlations between low income and low education and high use of the library as a meeting place were found, indicating that the library as a meeting place plays a substantial role in equalizing the possibilities of being an active citizen across social and economic differences. The study contributes to understanding the role of the public library in a multicultural context. The public library as a unique and complex meeting place has important implications for future librarianship.
\end{abstract}

\section{Introduction}

Both researchers and practitioners in the public library field have in recent years studied the public library as a meeting place and as an institution with the potential to build community and citizenship (see, for example, Audunson, 2005; Buschman, 2003; Fisher, Saxton, 
Edwards \& Mai 2007; Goulding, 2005; McCabe, 2001). This interest is, to a large extent, related to society becoming more and more complex and fragmented due to the growth of multiculturalism and digitization and the resulting need for meeting places with the capacity to promote (a) social inclusion, and (b) that minimal degree of communality in values, norms and bridging social capital that citizenship presupposes. Two dominating trends that shape today's society are digitization and multiculturalism (Castells, 2000; Wood \& Landry, 2008). The project Public Libraries - Arenas for Citizenship (PLACE), which received funding from the Norwegian Research Council for the period 2007-2011, use these trends as its background. Both developments hold promises. For example, digitization increases the number of people that form a community (Qvortrup, 2000). It also opens up new ways of communication between citizens and politicians and between citizens and citizens, i.e., increased participation in democracy. And multiculturalism can open up a fruitful and dynamic exchange between people of different cultures.

If these promises are to be realized, however, there must exist places to promote communication and generate a critical mass of communality in norms and values across cultural, ethnic, generational, and social lines. Creating such arenas is a far from trivial task. Does the public library, as an institution used by all segments in society, have potential in this respect? This is the general research agenda of the PLACE project.

\section{Problem statement}

Public libraries function as meeting places but with a few exceptions, empirical research and data are lacking on the extent to which they used as meeting places and the kinds of meetings that take place there. Empirical research exploring such questions is important in order to bring research beyond theoretical speculation, and it is important for the field of practice in its efforts to develop public libraries as meeting places. 
Previous research on public libraries as meeting places is partly contradictory in its results (Fisher et al., 2007; Leckie \& Hopkins, 2002) and focuses on the preferences of the public (Evjen \& Audunson, 2009) or the opinions of librarians on the library's potential as a meeting place (Goulding, 2005). There is a severe lack of empirical studies on how libraries are actually used as meeting places. We have not identified any empirical research on the different categories of meetings that actually take place in the public library. The research reported here contributes to bridging this gap. It does so by developing and proposing an instrument to measure meetings taking place in the public library.

\section{Literature review}

There is a relatively large amount of research on the impact of public libraries with regard to promoting community (Aabø, 2005; Debono, 2002; Kerslake \& Kinnel, 1998). Over the last 5 to 10 years, there has also been a significant increase in interest in the public library's role and its potential as a meeting place, both within the field of research and the field of practice. Leckie and Hopkins (2002) studied the main libraries in Vancouver and Toronto as meeting places, and they found that approximately $30 \%$ of users came to the library with others, whereas approximately $70 \%$ came alone. Although they conclude that the main libraries in these two cities are highly successful as public spaces, the respondents ranked the library low as a place to socialize and as a provider of community information. This finding is contradicted in a study conducted by Fisher et al. (2007), who investigated the main library in Seattle. They found that the library is regarded and used as a social place; their respondents stressed the social quality of visiting the library. Although a little less than $25 \%$ of users came to the library in the company of other people during the period of data collection, more than $50 \%$ reported that from time to time they come to the library with other people for social purposes. A high number of respondents reported that using the library has a clear social 
dimension in the sense that they were doing things for family and friends during their library visit. Goulding (2005) found that the public library has a strong potential as a meeting place. "Although a user may not actually talk to anybody during their visit to the library, the feeling of community can still be strong, encouraging a sense of belonging and solidarity” (p.357). Evjen and Audunson (2009) performed focus group interviews in two Norwegian cities and found that the perceptions of the library as a meeting place tend to be very complex: The library was simultaneously considered a cathedral and a daily living room with a low threshold to access. When the respondents were invited to describe the library as a person, it was generally described as combining opposite qualities in one person, for example the qualities of a heavy rocker with those of a singer in the tradition of Celine Dion.

SkotHansen (2001) has categorized the library as space on a theoretical and analytical basis. She opens up for different kinds of space, e.g., the library as a moral space, a social space, and a politological or public sphere space.

In studying the potential of public libraries as meeting places and trust generating places, the concept of social capital is applied, both in the social version (of which Robert Putnam is a leading representative) and in the institutional version. This theoretical point of departure is presented, discussed, and developed in several articles by researchers in the PLACE project (Audunson, Vårheim, Aabø, \& Holm, 2007; Vårheim, 2007a, 2007b; Vårheim, Audunson, \& Aabø, 2008; Vårheim, Steinmo, \& Ide, 2008; Vårheim, 2009).

In social capital research, there are two forms of social capital: bonding social capital in the form of networks and thick confidence (particularized trust) between members of tight and highly integrated groups; and bridging social capital in the form of networks and thin confidence (generalized trust) across primary belongings. 
In order for the positive promises of multiculturalism to be realized, it is necessary to build bridging social capital in the form of arenas where people are exposed to other values and interests than those they adhere to themselves. A Norwegian historian of ideas maintains that one of the important values of newspapers and libraries is that they expose their users to the complexity of values and interests in the world, forcing them to reconcile themselves with that complexity (Eriksen, 1988). Such arenas are called low-intensive meeting places, as opposed to the high-intensive meeting places where people live out their primary involvements and life projects (Audunson, 2005). People who share interests and values - whether they sing in a choir, support the same football club, share religious or political views - tend to find each other. The locations of such associations, which are termed high intensive meeting places, tend therefore to develop spontaneously and voluntarily.

The role of public authorities in creating high-intensive meeting places is limited to ensuring that freedom of association is secured both legally and when it comes to resources, such as providing space, offering financial support, etc. This is, however, not the case with lowintensive meeting places. The deeply devoted black-metal enthusiast probably feels a need to associate with other black-metal enthusiasts, but he or she may not, when meeting with fellow enthusiasts, also want to be exposed to the viewpoints and musical tastes of lovers of opera and country music enthusiasts, and vice versa. Low-intensive meeting places that open up for exposure to (and thus accept as legitimate) other values and interests than the ones people already cherish need to be consciously planned and constructed. The public library, which is frequented by most groups in the community, could be a point of departure for developing low-intensive meeting places that civil society needs.

The essence of the concept of low-intensive meetings is that at such meetings the participants are exposed to otherness, i.e., values and interests different from those the person in question cherishes, whereas the essence of the concept of high-intensive meetings is that 
participants meet with people with whom they already share values and interests. The level of intensity does not necessarily refer to the temperature in the level of activity. A politically active person attending a meeting in the local branch of the party of which he or she is a member confirms, through attending that meeting, his or her political belonging. Even though the atmosphere might be relaxed, such meetings are categorized as high intensive. If the person in question attends a meeting where representatives from different political parties present their views to each other and discuss, the temperature might be considerably higher. But since the participants are exposed to otherness, such meetings are defined as low intensive. The public sphere is characterized by communication between different interests and values. Public sphere meetings, therefore, are mostly low intensive. If communication is not to collapse, the intensity and temperature at such meetings where different values are exposed to each other cannot be too high. In that sense, there is a relation between lowintensive meetings and the degree of intensity of conflict.

When public libraries organize meetings, they seldom invite participants adhering to a specific set of values. More often, they invite community members across such affiliations. Therefore, they tend to be low-intensive, public-sphere meetings.

\section{Research questions}

The main research questions explored in this article can be summed up as follows:

1. Are the public libraries in three townships in Oslo used as meeting places, and if so, what kinds of meetings take place in the library? Do they function as low-intensive meeting places, where participants are exposed to the community in all its complexity? Do they function as a high-intensive meeting place where a person lives out his or her interests 
together with friends and colleagues? Do they function as a part of the public sphere, promoting citizenship and civic skills?

2. What can explain the varying intensity of using the local public library as a meeting place, where intensity is defined as the number of different kinds of meetings people report to have experienced in the public library? Demographic variables such as education, age, and income are important in explaining variation in library use in general. People with high education, for example, use the library more than do people with low education. Are such variables important also in explaining variations in use of the library as a meeting place, and is the direction of dependancy the same as for library use in general? What about users' ethnic and linguistic background? Do townships with markedly different demographic profiles have different needs for meeting places, and do the demographics of townships help explain differences in intensity of use?

3. Which categories of meetings take place in the library, and what can explain variations in the use of different kinds or categories of meetings? What is the explanatory power of township and demographic variables in this respect?

\section{Procedure}

\subsection{The research design}

In this study, a survey instrument was developed to elicit the use of public libraries as meeting places. Multiple regression analysis was used to analyze the responses. The survey was undertaken in March 2006 in three townships in Oslo, the capital of Norway, and the medium-large city of Troms $\emptyset$ in the north of Norway. A professional survey organization administered the survey, sampling, and interviewing based on a questionnaire designed by the research group. In each of four communities, 250 respondents were drawn randomly from a 
database of telephone numbers. Thirty percent of the 1,000-person sample used cell phones. In this kind of survey research, the polling organization continues until the agreed upon number of respondents have been reached. The polling organization weighted the sample according to gender and age. The procedure used is identical with the one generally used by polling organizations when doing telephone surveys. Thus, the results can be generalized from the samples to the populations they are drawn from (Ringdal, 2007). The interviews were done via phone, and each interview lasted for about 12 minutes.

In this article, the data from the three townships in Oslo is analyzed. The focus is on how the inhabitants of three distinctly different local communities within a metropolitan city used their local libraries as meeting places, rather than on regional differences. The study investigated if and how the demographic composition of a community (e.g., along ethnic and social lines) affects the library's role as a meeting place. The three townships, denoted as the gentrified community, the multicultural community, and the middle class community, are markedly different along such dimensions.

The gentrified community is located in the eastern part of the inner city of Oslo. It has strong roots in industrial and working class traditions. Some of the major manufacturing enterprises in Oslo were located here, and historically most of the inhabitants belonged to the working class. As traditional industries closed down, the township went through a process of gentrification. Its demographic composition is complex: Among the older inhabitants there is still a substantial proportion with their roots in the working class. Gentrification brought in new population strata, and because of this, the average level of education is high. Statistics from the municipality of Oslo (Oslo kommune, 2009) show that almost 50\% of the adult population has one year or more of university or college education. The city average is 40 percent. Approximately $17 \%$ of the inhabitants are immigrants with a non-Western background. One important characteristic of this township is the age distribution. There is a 
very high proportion of young adults and few children: $53 \%$ of the population is between 20 and 39 years. (The corresponding figures in the multicultural and middle class community are 28 and $24 \%$, respectively.) Only $12 \%$ are below 16 years of age compared to 26 and $21 \%$ in the two other townships. A high number of apartments in the gentrified community are reserved for public housing. The number of social service clients, therefore, is relatively high. Since the early 1990s, the local library has been very active in community building, in particular with immigrant girls and women as their target group. It was awarded with the national Library of the Year prize for that work in 1996. Politically, this township is left wing. Fifty-six percent of the vote was for social democratic and socialist parties in the last local elections (Oslo kommune, 2009).

The multicultural community is a suburban development south of the city center. It was completed in the beginning of the 1980s. Although it contains some middle class districts, the proportion of the population with one year or more of university or college education is considerably below the city average, about 15 percent below. Out of the 15 townships of Oslo, it ranks as number 12 in terms of educational level. The proportion of inhabitants with a non-Western background is $36 \%$, one of the highest in Oslo. In schools, the proportion of pupils belonging to a linguistic minority is $56 \%$ compared to the city average of $37 \%$. In one school, $94 \%$ of the pupils have a non-Western background. The local library has been active in community building and particularly in combating racism. This library has also been awarded the national Library of the Year prize. Politically, the social democratic and socialistic parties achieved a $55 \%$ of the vote in the last local elections.

The middle class community is situated in the western part of the city. Here the number of non-Western immigrants is only $6 \%$, considerably below the city average of approximately $20 \%$. The proportion of the adult population with one year or more of university or college education is close to $55 \%$, one of the highest rates in Oslo. The income level is also well 
above the city average. In fact, the average income in the middle class community is the top in the city. Only one township has a lower average income than the multicultural society, and the gentrified community's income level is close to the city average. Politically, the middle class community is strongly right wing. The left wing parties achieved only $23 \%$ of the vote in the last local elections.

\subsection{The questionnaire}

The dependent variable in this study is the role of the library as a meeting place as reflected in actual use. The terms meeting and meeting place have many dimensions in social science in general and also in library and information science-for example, public sphere meetings in the Habermasian sense, which promote communicative action, i.e., a process of undistorted communication where the participants search for a mutual understanding based on the power of the better argument (Habermas, 1989; Buschman, 2003; Skot-Hansen, 2001); informal third place meetings (Oldenburg, 1999); the distinction between front stage and back stage (Goffman, 1959); and meetings between strangers in the public realm (Lofland, 1973; Lofland, 1998; Sennett, 2002). In developing questions on different kinds of meetings, the PLACE research group has taken inspiration from all the above works, including questions such as: Have respondents attended public meetings in the library (the library as a public sphere)? Have they met accidentally with friends and neighbors (the library as an informal third place)? Have they worked with friends and colleagues on a joint project or common interest (the library as a high-intensive front stage)? Have they met and entered into conversation with strangers (the library as a square and a public realm)?

In addition to measuring face-to-face meetings taking place in the library, two questions were included to elicit the library's role as a facilitator for meetings taking place outside the library. One (the library as a metameeting place) measured the extent to which people use the library to identify organizations and activities they want to participate in, e.g., joining a chess 
club, a choir, or a sports club. The second one aimed at determine the library's role in helping a person engage in social and political community issues.

Meetings vary in intensity of communication. Before children start to play role games, they play parallel, sitting side by side in the sandbox. Many meetings between adults have the same character. People might prefer, for example, to study in the library because they find it stimulating to sit together with other students. This is similar to the fact that many people choose to do their push-ups and sit-ups in expensive fitness studios instead of for free at home. Other meetings depend on intense communication. Meetings, then, can be placed on a continuum, with parallel activities at one end and intensive cooperation and communication at the other. Meetings also vary according to instrumentality. Some are highly instrumental, e.g., a group of students working together in the library to complete an assignment in connection with their education. Others are less instrumental, e.g., a group of users sitting together in the newspaper corner relaxing with a magazine or newspaper. Meetings vary according to purpose, e.g., for learning, entertainment, or the fulfillment of social and emotional needs. A battery of questions was developed to cover such dimensions. These questions and the indexes constructed on the basis of them are presented in the next section.

In other parts of the questionnaire social capital in the three communities is measured by exploring the degree to which respondents took part in voluntary associations and activities and their confidence in a number of community institutions at the local, city, and national level. The question on activities in voluntary organizations is inspired by one dimension in Putnam's (2000) way of measuring social capital, whereas trust in community institutions is adapted from a question in the project European Social Survey (ESS, 2009). The respondents were also asked if they have tried to improve conditions in the local community through different activities, e.g., contacting politicians or signing petitions. 
In the process of developing the questionnaire, the project group had in-depth conversations with public librarians from the field of practice as well as with researchers from the professional survey organization engaged to undertake the sampling and data collection for this study; these librarians and researchers had important input.

\subsection{The sample}

The sample corresponds with the demographic composition in the three communities along the variables of gender, age distribution, income, etc. There are however two important exceptions to this: education and the proportion of respondents with a non-Western cultural and linguistic background. The biases are first and foremost to be found in the multicultural township. Only $18 \%$ of the respondents from this township had such a background, whereas the proportion of the population in the township at the time of undertaking the survey was $36 \%$. In this township, approximately $30 \%$ had a high level of education, defined as one year of university or college education or more. In the sample from the multicultural township, as many as $52 \%$ of respondents had attained this educational level. In the two other townships, where the proportion with university education was close to $60 \%$, the sample corresponded with what was found in official statistics.

The biases in the sample from the multicultural community are probably related to the fact that the interviews were undertaken in Norwegian only. Interviewing in the different languages represented in the community would have been too expensive to undertake. Respondents, therefore, had to master Norwegian at a relatively advanced level. Due to this, the immigrant respondents probably deviated from immigrants in general both in linguistic skills and educational level. It is for this reason that we decided not to use weighting for ethnic and linguistic backgrounds. This bias might have affected our results in terms of how the immigrant population uses the library as a meeting place. We plan to conduct a qualitative 
follow-up study within the project that focuses on immigrant women who will be interviewed in their mother tongues.

\subsection{Statistical analysis}

In analysing the data, multiple regression analysis was used both in its linear and logistic versions. The design of the regression analyses is presented in detail in the next section.

\section{Findings}

\subsection{Is the library used as a meeting place?}

Our first research question sought to explore how and to what extent the public library is used for meetings that vary in degree of communication, instrumentality, purpose, sphere of life or role (student, employee, parent, relative or friend) in which they are held, etc. The 750 respondents from three urban districts in Oslo were asked if they could remember using the public library for different kinds of meetings (see Table 1). The respondents were asked to report their experiences in general rather than within a given time period, such as the last six months or last year.

\section{"Take in Table 1"}

Table 1 gives an indication of how and to what extent the public library is used as a meeting place. The table presents the different kinds of meetings in order of popularity. The findings show that the library is used in this capacity to a great extent. Almost $40 \%$ of respondents stated they have observed people different from themselves in the library, whether from 
another age-group, cultural background, or other difference. Almost one third of the respondents accidentally met neighbors or friends in the library, and as many as $28 \%$ got into conversations with strangers. Twenty-five percent who went to the library learned about political or cultural organizations or leisure activities taking place in the local community. More than $20 \%$ went to the library with friends or colleagues to work together on a common assignment or a leisure activity. Seventeen percent used the Internet at the library to contact friends via e-mail, for chatting, or to participate discussion groups, etc. Sixteen percent used the library to learn more about local matters, social or political issues, etc., that they are involved in. Fourteen percent participated in organized meetings, such as author's nights, lectures, meetings with politicians, etc. Ten percent used the library as a place to meet family or friends before going together to the movies, into the city, to do shopping, etc.

\subsection{Using multiple regression analysis to study how the library is used as a meeting place}

To what extent can variations in the use of the public library as a meeting place be explained, and which variables are important in this respect? This is the second research question. To analyze the variation of use shown in Table 1, multiple regression analysis was applied, which is a set of techniques that can be used to explore the relationship between one dependent variable and a number of independent variables or explanatory factors.

There are three major types of multiple regression analyses - (a) standard or simultaneous, (b) stepwise, and (c) hierarchical or sequential. In hierarchical regression, which is used in the analyses in this study, the independent variables or explanatory factors are included in blocks. The research group decided on the composition of blocks on theoretical grounds, i.e., the explanatory factors to constitute each block, and then the order of the blocks to be included in the regression analyses. The independent variables included in the analysis were divided into four blocks. To explore if and how the demographic composition of the townships has an effect on how the local library is used as a meeting place, the first block was decided to 
consist of dummy variables denoting the three markedly different communities under study, to investigate their overall effect. Several independent variables making up the demographic profiles of the respondents were included in the second block to investigate the individual effects as well as the effect of the block as a whole. In addition to demographic variables, the third block included variations in the respondents' reported local activities and their engagement and trust in community institutions. These explanatory factors were considered of interest for if and how respondents used the library as a meeting place. The fourth block consisted of respondents' frequency of library use, which was supposed to have a great effect. Hierarchical regression makes it possible to investigate the effect each block has on the explanation of the variance in the dependent variable, after the previous variables have been controlled for. The effect is shown by the adjusted $R^{2}$, displayed in Table 3, described below ${ }^{\mathrm{i}}$.

\section{"Take in Table 2"}

In Table 2 the four blocks and the variables they include are described. The first block is made up of dummy variables denoting the three urban districts studied: the multicultural community and the gentrified community, with the middle class community chosen as the reference category. Our assumption was that since these communities had a markedly different demographic composition, the respondents' geographical home would influence their use of the local public library as a meeting place. The second block is made up of independent socioeconomic variables including main occupation, age, education, cultural and linguistic background, and household income. The assumption was similar to that of block one, that specific socioeconomic differences would explain some of the variation in respondents' use of their local public library as a meeting place. 
The third block differs from the previous two. It consists of three constructed indexes measuring different characteristics of the respondents based on their activities and attitudes. The first independent index, participating in local activities, sums up how many activity types respondents participated in, such as organized sports, leisure, culture, hobbies, housing cooperation work, local political organizations, religious activities, or open cultural arrangements. The next index, improvement activity, measures how engaged the respondents were in trying to improve conditions in their local community, e.g., by contacting a local politician or civil servant in the local community or municipality, participating in a political party or action group, participating in other organizations or associations, signing a petition on a current local matter, donating money to a political organization or group in the local community, attending a local protest march, or attending an illegal protest or action. The third index, community inst. trust, measures how much trust respondents had in different community institutions, e.g., the community council, city parliament, parliament, schools, police, and public library. Trust in these types can be interpreted as components of social capital.

In the fourth block, library use is measured. The independent variable library use freq measures the respondents' frequency of use of their local libraries ${ }^{\mathrm{ii}}$. It was hypothesized that respondents who were frequent library users also used the library as a meeting place for most kinds of meetings.

All the independent variables intended for use in our analyses were screened for multicollinearity ${ }^{\mathrm{iii}}$. None of the bivariate correlations between each of the 16 independent variables was statistically significant (their Pearson correlation coefficients ranged from $r=$ 0.000 to $r=0.500$ ). In addition, the diagnostic measures of tolerance and variance inflation factor $^{\text {iv }}$ (VIF) for each of our explanatory factors were checked, displayed in Table 3. They indicate that the multicollinearity assumption is not violated and thus all the independent 
variables were included in the analyses. The same four blocks were used in all seven regression analyses. In Table 3, the adjusted $\mathrm{R}^{2}$ is displayed for all four blocks to show the increase of explanatory power of the independent variables as each of the blocks are entered into the regressions, as described below.

What can explain the fact that some respondents used the library for a wide range of meetings, while others used it as a meeting place only in a limited capacity? This question was examined by analyzing the dependent variable meeting intensity, constructed as an index measuring the intensity, i.e., the use of the library for up to nine different kinds of meetings. The index with scores from 0 to 9 is based upon the respondents' answers to the questions about which kinds of meetings in the library they have participated in (displayed in Table 1). This dependent variable was studied in a linear hierarchical regression analysis entering each of the four blocks of independent variables described above. The results are shown in Table 3.

"Take in Table 3"

In block 1 of Table 3, the independent variable gentrified community is positive and highly significant, showing that respondents living in this urban district are more likely to use the library for more kinds of meetings than respondents living in the middle class and multicultural communities. However, the adjusted $\mathrm{R}^{2}$ listed at the bottom of the table tells how much of the variance in the dependent variable meeting intensity that is explained by the model so far. In block 1, local geographical belonging counts for only $2.6 \%$ of the variance in using the local library for meetings (Adj. $\mathrm{R}^{2}$ Block $1=0.026$ ).

In block 2, only two of the socioeconomic explanatory factors are significant. Cultural linguistic background is significant at the 5\% level and is strongly negative, showing that respondents with a cultural and linguistic background other than Norwegian use the library as a meeting place in more ways than those with a Norwegian background. This result accords 
with findings in surveys of library use of urban libraries in Norway and Scandinavia (ABMutvikling, 2008; Hvenegaard Rasmussen \& Høirup, 2000; Vaagan, 2005). The independent variable household income is highly significant and negative, showing that respondents with lower household income use the library for more kinds of meetings than people with higher household income. Looking at adj. $\mathrm{R}^{2}$ for block 2 , the explanation of variance in the dependent variable has increased, but just slightly, now counting 3.5\%.

In block 3, the indexes measuring respondents' participation in local activities as well as their engagement in improving the local community are positive and highly significant. This shows that respondents who participate in many types of activities in the local community also use the library as a more varied meeting place (participating in local activities index), compared with respondents who are less active. Respondents more engaged in trying to improve the conditions in the local community (improvement activity index), attend more kinds of meetings in the library than those who are less engaged in improvement activities. The index that measures trust in community institutions is slightly positive but not significant. Looking at adjusted $\mathrm{R}^{2}$ for block 3, a marked difference is shown. Now the explanation of variance in the dependent variable has increased considerably, to $21.2 \%$.

Block 4 enters the independent variable measuring the frequency of respondents' use of their local library (library use freq) ${ }^{\mathrm{v}}$. It is, as expected, positive and significant at the $1 \%$ level, showing that frequent library use correlates with a varied use of the library as a meeting place. Adjusted $\mathrm{R}^{2}$ increases to 0.0296 , explaining almost $30 \%$ of the variation of the meeting intensity, which is in line with other library analyses of this type. Studies analyzing the use and non-use and the value of public libraries seldom explain more than approximately $30 \%$ of the variance (Aabø, 2005; Audunson, 1995; D'Elia, 1980; Zweizig \& Dervin, 1977). 


\subsection{Different categories of meetings in the library}

The third research question examines the different distinctive kinds of meetings that take place in the local library. Are there significant variations in the use of the library for the different kinds or categories of meetings and, if so, what can explain the variation? The meetings in the library were categorized based on the theoretical approaches presented in section 5.2., i.e., theories on the public sphere, theories on meetings between strangers in the public realm, informal third-place meetings, and the authors' definition of high-intensive versus low-intensive meetings in section 3. Based on a categorization of the nine types of meetings listed in Table 1, six indexes were constructed:

1. The variable square aims to catch the library as a low-intensive meeting place. It is based on the questions about accidental meetings with friends and neighbors, entering into conversation with strangers, making appointments to meet at the library to go somewhere else and, finally, encounters with people different from themselves. See Table 1, questions 1-3, 9. 2. The variable meet diff people is also focused on the library as a low-intensive meeting place but concentrates only on the question of having encounters with people different from themselves. See Table 1, question 1.

3. The variable public sphere aims to elicit how the library is a part of the public sphere, based on the question related to respondents' participation in meetings with authors or politicians, and on the question on searching information on community issues. See Table 1, questions 7-8.

4. The variable joint activities aims to catch high-intensive meetings and is based on the question about meeting at the library with friends, classmates, or colleagues to work together on a common assignment or leisure time activity. See Table 1, question 5 . The variable metameetings explores the library as a metameeting place based on the question related to 
using the library to find information about organizations and activities in the local community. See Table 1, question 4.

6. The variable virtual meetings catches the library as a virtual meeting place. See Table 1, question 6.

In exploring the differences between various demographic and social groups in the way these categories of meeting types are used, each of the six indexes were studied as dependent variables. (See the last part of Table 2.) These dependent variables are all dichotomous, given the value 1 if the respondent used the library for such a meeting place and the value 0 if not. To investigate the relationship between each of the six meeting types and the independent variables, logistic regression was used. This statistical method of analysis is appropriate for categorical dependent variables that are dichotomous in nature (Pallant, 2007).

"Take in Table 4"

The explanatory factors were entered into the hierarchical logistic regression analyses in the same four blocks as in the linear regression analysis shown in Table 3. Table 4 displays the results of the logistic regression analyses of the six categories of meeting types. Looking at block 1 in Table 4, the urban district variable is statistically significant for four of the six meeting types. Thus there appears to be differences according to community characteristics. The role of the library as an arena where users are exposed to the complexities of a multicultural society is most significant in the multicultural community and among people with non-Western cultural backgrounds. Respondents living in the multicultural community are more likely to be using the library as a square compared to residents of the gentrified and middle class communities. For the dependent variables meet diff people that focuses on 
whether respondents notice people different from themselves, and metameetings, the independent variables for both the gentrified and the multicultural communities are positive and significant. The library as an arena for virtual social activitiesis most important in the gentrified community. This independent variable is positive and significant, showing that respondents living in the gentrified community are more likely to use the library in this capacity than residents of the other two local communities. The dependent variables public sphere and joint activities both focus on high-intensive meetings, but for them the independent variables describing urban districts are not statistically significant.

In block 2, the dummy variables denoting the respondents' main occupation (e.g., working, job seeking, or being a homemaker, student, or retiree, with the latter as the reference category) indicate relatively small significance. It is only for the virtual meeting type that two of the main occupations are statistically significant at the 5\% level and positive. Respondents who are job seekers or homemakers heavily use the library in this capacity compared to respondents with other main occupations. The independent variable age old $\rightarrow$ young is negative and significant at the $10 \%$ level in the public sphere, showing that respondents tend to use the library as a public sphere more with growing age. For joint activities and virtual meetings, the independent variable age old $\rightarrow$ young has the opposite sign but is highly significant, at the $1 \%$ and $5 \%$ level, respectively. This indicates, as expected, that young people use the library more for joint activities with friends, classmates or colleagues and as a virtual meeting place than older people. For the dependent variables square and joint activities, the explanatory factor education is negative and significant at the $10 \%$ level, indicating that respondents with less education use the library more, both as a low-intensive and as a very high-intensive meeting place than those with more education. 
The explanatory factor cultural and linguistic background is highly negative and significant for the meeting types square, joint activities and virtual meetings, showing that people with a background other than Norwegian use the library considerably more in these capacities than people with a Norwegian background.

Several of the independent variables in block 2 are significantly correlated with performing joint activities with friends and colleagues in the library. The explanatory factors of age (youth), education (low education), cultural and linguistic background (immigrant from a nonWestern background) and household income (low income) are significantly correlated with using the library as a high-intensive arena for joint activities with friends or colleagues. The same pattern is seen for those using the library for virtual meetings, except here the explanatory factor education is not significant. It has the same sign but is considerably weaker.

Household income is significant and negative for the three high-intensive meeting types public sphere, joint activities and virtual meetings, showing that people with lower incomes use the library for such kinds of meeting to a higher degree than high-income respondents. Another important finding is that young people, immigrants, and people with low household incomes tend to use the library more for social purposes than people who are older, with a Norwegian background, and with a higher household income. Each of these explanatory factors is significant when controlled for all the other independent variables in the models. This result corresponds well with other studies. A large-scale observation in the main libraries in Norway's five largest cities found that first and foremost youngsters and users with a nonWestern background come to the library in the company of others and perform social activities during their visit (ABM-utvikling, 2008).

The six hierarchical logistic regression analyses of different categories of meetings contain the same 16 independent variables in four blocks. The six full models are all statistically 
significant $^{\mathrm{vi}}$, indicating that the models distinguish between respondents who answered that they had or had not used the library for each of these categories of meetings. In other words, the independent variables taken together are significantly associated with the use or nonuse of these six meeting types in the public library.

The amount of variance in the dependent variables explained by the models is indicated by Nagelkerke $\mathrm{R}^{2}$, which is a statistic comparable to the adjusted $\mathrm{R}^{2}$ in linear regression analysis (Sin \& Kim, 2008). Nagelkerke $\mathrm{R}^{2}$ values give an indication of the amount of variation in the dependent variable explained by the model, with values ranging from 0 to 1 (Pallant, 2007). In our overall models analyzing the six different meeting types that take place in the library, the Nagelkerke $\mathrm{R}^{2}$ ranges from 0.195 to 0.277 (see Table 4), indicating that all the independent variables taken together explain from $19.5 \%$ of the variance in public sphere and up to $27.7 \%$ of the variance in square.

The hierarchical technique was applied in the logistic regression analyses, as in the linear regression, in order to explore the explanatory power of the different types of independent variables. Focusing on the explanatory power of the four blocks in the models on the variance between the six kinds of meetings, the urban districts in block 1 and the socioeconomic variables in block 2 are shown to have relatively small explanatory power. Taken together, they explain from about $5 \%$ of the variation in the use of the library as a metameeting place to find information about organizations and activities in the local community (Nagelkerke $\mathrm{R}^{2}=$ 0.049 ), up to almost $17 \%$ of the variation in virtual meetings in the library (Nagelkerke $\mathrm{R}^{2}=$ 0.167). A big leap comes with block 3, whose indexes represent the respondents' participation in the local community, their improvement activities, and their trust in community institutions. Now the explanatory power increases considerably, from about $12 \%$ in metameetings (Nagelkerke $\mathrm{R}^{2}=0.118$ ) up to $23 \%$ in virtual meetings (Nagelkerke $\mathrm{R}^{2}=0.234$ ). 
These results follow the same pattern as found in the linear regression analysis of meeting intensity.

When entering block 4, the library use frequency of the respondents, an interesting change occurs. The explanatory power continues to increase substantially for the four meeting categories - square (from $18 \%$ to $28 \%$ ), meet diff people (from $12 \%$ to $23 \%$ ), public sphere (from $16 \%$ to $20 \%$ ), and metameetings (from $12 \%$ to $20 \%$ ) - and thus follows the same pattern as in the linear regression. But the situation is quite different for two of the meeting types. For high-intensive meetings involving friends, classmates, or colleagues working together on a common task or leisure time activity (joint activities), adding block 4 to the independent variable library use frequency does not increase the explanatory power at all; it is $21.6 \%$ after block 3 is entered and remains $21.6 \%$ when also block 4 is entered. For virtual meetings, the increase is only minimal, from $23.4 \%$ to $23.5 \%$. What can explain this marked difference between the meeting categories? Joint activities and virtual meetings are used more by younger people compared to the other meeting categories, as seen by the highly positive and significant logit coefficients on the independent variable age old $\rightarrow$ young: 0.391 and 0.390 respectively. Household income for respondents using these two meetings types is clearly lower than for users of the other meeting types, shown by the logit coefficients -0.334 and -0.376 respectively. Joint activities and virtual meetings are also used more by respondents with a cultural and linguistic background other than Norwegian, compared to the other meeting categories, except for square.

\section{Discussion}

Respondents with less education are shown to use the library more as a low-intensive meeting place as well as a high intensive meeting place, square and joint activities respectively. This is a very interesting find, which contrast findings in studies of general 
library use. In several studies of library use (Audunson, 1995; D'Elia, 1980; Sin \& Kim, 2008), there is a strong positive correlation between high education and library use, indicating that people with higher education use the library more than people with lower education. Our analyses suggest that people with lower education use the library more as a low-intensive meeting place (square) than people with higher education. To use the library as a square does not need preparation or special purposes or intentions, but simply acting off the cuff. Perhaps people with lower education are more inclined to use the library as such a meeting place? On the other hand, respondents with lower education also use the high-intensive kind of meeting, joint activities, more often compared to those with higher education, according to the findings. More research is needed to test the consistency of these findings and examine their possible interpretations.

Respondents with lower household incomes are shown to use the library for the three highintensive meeting categories, public sphere, joint activities, and virtual meetings, more frequently than people with higher household incomes, when controlled for the other independent variables. A reasonable explanation is that a considerable proportion of joint activities is related to students engaged in educational projects; they are a low-income group, since the majority of students in Scandinavia do not live with their parents but make up oneperson households. Also, the groups most heavily using ICT for virtual meetings are below the age when most people reach the income peak of their career. An important category of public meetings taking place in the library—so-called senior citizens' universities — has people on retirement pension as their primary target group.

It is interesting to note how the effects of the four blocks of independent variables vary between the different categories of meetings, as seen in Table 4. The urban district has a small effect as an explanatory factor for variation in use of all the meeting types, but is quite inconsequential for the library as a public sphere and for joint activities. Demographic 
variables add only a little more to the explanation for most meeting categories, but it is worth paying attention to the two high-intensive meetings, joint activities and virtual meetings, which explain $14 \%$ and almost $17 \%$, respectively. Block 3 (community involvement/social capital) has the greatest effect on all categories of meetings, but particularly on using the library as a square and on using the library as a citizen (public sphere), increasing explained variance with approximately 13 and $11 \%$, respectively. Its effect is somewhat less, however, for meeting categories where users are exposed to otherness (meet diff people), are performing joint activities with friends and colleagues, or are participating in metameetings and virtual meetings. Its importance in relation to using the library as a square is intuitively understandable. Bumping accidentally into friends and neighbors and entering into conversation with strangers are two of the aspects of this dependent variable. It seems reasonable to presuppose that those being active in several community organizations and involving themselves in activities to improve conditions in society will know more people they can bump into than the more inactive. It also is reasonable that they will enter into conversation with strangers, partly because people who are socially active in the local community probably are more than average social and outgoing, partly because they might by regarded by others as ombudsmen and approached by strangers in that respect.

Block 4, with the independent variable library use frequency, is particularly related to the two low-intensive categories of meetings: square and meetings with people different from themselves. That the frequent library users more often than those visiting the library less frequently are exposed to the complexity of the local community is quite natural. It is also interesting that this block does not contribute at all to joint activities in the library and the use of the library for virtual meetings. How can this be explained? One reason might be that these meetings are more instrumental than those in the other categories? People may go to the library with friends and colleagues to work on a common task every time the task in question 
makes it necessary. In between recognized needs, they have no reason to go to the library in relation to that task. The square category of meetings is probably far less instrumental. It seems reasonable to hypothesize that people using the library in that way do it because they like it, not due to some instrumental need. Frequency of use is also related to using the library as a channel to find information about other arenas and activities in the community, i.e., using the library as a metameeting place.

Of the four blocks of explanatory factors, local community involvement is found to be unquestionably the most important block. The interpretation of this finding is not obvious, however. Does the library contribute to generating social capital or is the use of the library as a meeting place a result of preexisting social capital? It will take further research to analyze the strength and, first and foremost, the direction of this relationship. There is a need for further knowledge about the use of the library as a meeting place. To what degree is the library of today enhancing the bridging social capital in the local community it serves, and what can increase its contribution in this respect?

Important categories of meetings have been identified, but there is a need to know more about what people really are doing when they use the library for different kinds of meetings: What do they do when they come to the library with friends and colleagues, what do they do when using ICT for social purposes etc.? Another interesting question that will be analyzed in a upcoming paper is the extent to which people move between different categories of meetings, thus moving between different roles and life spheres and between low- and highintensive meetings. The concept of low-intensive versus high-intensive meeting places appears to be fruitful and needs to be more thoroughly examined. In what ways do people experience otherness in the library, and what is the effect of such experiences on trust? Does it increase trust or the opposite? Such issues will be addressed in future research within the PLACE project. 


\section{Conclusion}

The first research question aimed to explore to what extent and in what ways public libraries are used as meeting places. The results show that the libraries in the communities under study are used for a variety of meetings. The library is a meeting place functioning as a square, a place where people learn something about those different from themselves, a public sphere, and a place for joint activities, metameetings, and virtual meetings. The library appears to be a place, where in a safe environment and in an unobtrusive way, people are exposed to the complexity of the digital and multicultural society and learn something about multiculturalism.

In this way the library stands forth as a complex meeting place: It has some traits similar to those characterizing third places (Oldenburg, 1999). It cannot, however, be restricted to a third place. As a meeting place it is also related to home and family activities (first place) and work related activities (second place). Having said that, the whole story is not yet told. The library also appears to be a part of the public sphere in the Habermasian sense. But adding this dimension is still not enough to give an exhaustive description of the library as a meeting place. It is a place where people accidentally run into neighbors and friends, but it is also a place where a substantial proportion report being accidentally engaged in conversations with strangers. It appears to be a place where users are exposed to "the other," i.e., people with a background different from themselves. The library is thus used as an arena for both lowintensive and high-intensive meetings.

The second research question is related to variation in the intensity of using the library as a meeting place. What explains why some use the library for a whole range of different meetings, whereas others use it as a meeting place in a more limited capacity? The hypothesis was that townships with markedly different demographic profiles have different needs for meeting places and are shown to use the library differently in such a capacity. Contrary to 
such expectations, neither township (block 1) nor demographic variables (block 2) contribute very much in explaining the variance in the extent to which the library is used as a meeting place. The important block of variables is the one including indexes measuring local community participation, improvement, and trust in community institutions. This finding suggests there exists a relationship between social capital and the use of the library as a meeting place.

Turning to the different categories of meetings, the third research question, the findings here also run contrary to initial expectations. Township explains a negligible proportion of the variance, and socioeconomic variables play a significant role for only two categories of meetings (joint activities and virtual meetings). Explained variance increases significantly in both these cases. Engaging in such meetings is related to being young, having a non-Western linguistic and cultural background, having a low household income, and, for joint activities, also low level of education.

In explaining the variance of how the library is used as a meeting place, local community involvement is shown to be an especially significant explanatory factor. Demographic variables generally do not have a big impact, but there are two important exceptions. There is a constant correlation in the data between having a low income (public sphere, joint activities, and virtual meetings) as well as having a low education (square and joint activities) and using the library as a meeting place. This indicates that the library as a meeting place plays a substantial role in equalizing the possibilities of being an active citizen across social and economic differences.

The research presented here has implications for the field of practice as well as for the field of LIS research. Practitioners and researchers are increasingly interested in public libraries as meeting places, and the findings of this project could contribute to reflections on how to develop that dimension of public librarianship. The questionnaire developed might contribute 
to research on a dimension of public librarianship that existing research instruments have not been capable of eliciting satisfactorily. Further work is needed, however, to refine and develop the instrument, in particular its capacity to catch meetings across cultural and ethnic lines. 


\section{References}

Aabø, S. (2005). The value of public libraries: A methodological discussion and empirical study applying the contingent valuation method. Oslo: University of Oslo.

ABM-utvikling. (2008). Hvem er de og hvor går de? Om brukeradferd i norske storbybibliotek (ABM-skrift No. 46). Oslo: ABM-utvikling.

Audunson, R. A. (1995). Utvikling og testing av en kausalmodell for folkebibliotekbruk. Norsk tidsskrift for bibliotekforskning, 2(4), 59-78.

Audunson, R. A. (2005). The public library as a meeting-place in a multicultural and digital context: The necessity of low-intensive meeting-places. Journal of Documentation, 61(3), 429-441.

Audunson, R. A., Vårheim, A., Aabø, S., \& Holm, E. D. (2007). Public libraries, social capital, and low intensive meeting places. Information Research, 12(4), Retrieved October 17, 2008, from http://informationr.net/ir/12-4/colis/colis20.html.

Buschman, J.E. (2003). Dismantling the public sphere: Situating and sustaining librarianship in the age of the new public philosophy. Westport, CT: Libraries Unlimited.

Castells. M. (2000). The rise of the network society. Vol. 1. Oxford: Blackwell.

D'Elia, G. (1980). The development and testing of a conceptual model of public library user behavior. The Library Quarterly, 50(4), 410-430.

Debono, B. (2002). Assessing the social impact of public libraries: What the literature is saying. Australasian Public Libraries and Information Services, 15(2), 80-95.

Eriksen, T. B. (1988). Profesjonsetikk. Bok og bibliotek, 55(6), 4-6.

European Social Survey. (2009). The European Social Survey (ESS). Retrieved July 16, 2009, from http://www.europeansocialsurvey.org/. 
Evjen, S., \& Audunson, R. A. (2009). The complex library: Do the public's attitudes represent a barrier to institutional change in public libraries?" New Library World, 110(3-4), 161-174.

Fisher, K. E., Saxton, M. L., Edwards, P. M., \& Mai, J.-E. (2007). Seattle Public Library as place: Reconceptualizing space, community, and information at the central library. In J. Buschman \& G. J. Leckie (Eds.), The library as place: History, community, and culture (pp. 135-160). Westport, CT: Libraries Unlimited.

Goffman, E. (1959). The presentation of self in everyday life. Garden City, NY: Doubleday. Goulding, A. (2005). A community forum: UK public libraries as meeting places. In M. Langeland et al. (Eds.), Librarianship in the Information Age: Proceedings from the 13th BOBCATSSS-symposium (pp. 349-358).

Habermas, J. (1989). The structural transformation of the public sphere: An inquiry into a category of Bourgeois society. Cambridge, UK: Polity.

Hvenegaard Rasmussen, C., \& Høirup, C. L. (2000). Kulturinstitutionernes bidrag til det kulturelt mangfoldige Danmark: en undersøgelse af kunst-og kulturformidlingsinstitutioners tilbud til og inddragelse af de etniske minoriteter. København: Det Interkulturelle Netværk.

Kerslake, E., \& Kinnel, M. (1998). Reviewing the literature on public libraries and social inclusion. Libri, 48(1), 1-12.

Leckie, G. J., \& Hopkins, J. (2002). The public place of central libraries: Findings from Toronto and Vancouver. Library Quarterly, 72(3), 326-372.

Lofland, L.H. (1973). A world of strangers, order and action in urban public space. New York: Basic Books.

Lofland, L.H. (1998). The public realm: Exploring the city's quintessential social territory. New York: Aldine de Gruyter. 
McCabe, R.B. (2001). Civic librarianship: Renewing the social mission of the public library. Lanham, MD: Scarecrow Press.

Oldenburg, R. (1999). The great good place: Cafés, coffee shops, bookstores, bars, hair salons and other hangouts at the heart of a community. New York: Marlowe.

Oslo kommune. (2009). Statistisk årbok for Oslo. Oslo: Økonomiavdelingen.

Pallant, J. (2007). SPSS survival manual / a step by step guide to data analysing using SPSS for Windows (3rd ed.). Maidenhead: McGraw-Hill, Open University Press.

Putnam, R.D. (2001). Bowling alone: The collapse and revival of American community. New York: Simon \& Schuster.

Qvortrup, L. (2000). Det hyperkomplekse samfund: 14 fortcellinger om informationssamfundet (2nd ed.). København: Gyldendal.

Ringdal, K. (2007). Enhet og mangfold: Samfunnsvitenskapelig forskning og kvantitativ metode. Bergen: Fagbokforl.

Sennett, R. (2002). The fall of public man. London: Penguin.

Sin, S. C. J., \& Kim, K. S. (2008). Use and non-use of public libraries in the information age: A logistic regression analysis of household characteristics and library services variables. Library \& Information Science Research, 30(3), 207-215.

Skot-Hansen, D. (2001). Folkebiblioteket i civilsamfundet - civilsamfundet i folkebiblioteket. In R. Audunson \& N. W. Lund (Eds.), Det siviliserte informasjonssamfunn: Folkebibliotekenes rolle ved inngangen til en digital tid (pp. 45-62). Bergen: Fagbokforlaget.

Vaagan, R. (2005). Bibliotekene og det flerkulturelle Norge. Oslo: ABM-utvikling. Vårheim, A. (2007a). Social capital and public libraries: The need for research. Library \& Information Science Research, 29(3), 416-428. 
Vårheim, A. (2007b). Social capital and the multiethnic challenge: The role of the public library. In R. Sharma (Ed.), Social Capital: An introduction (pp. 100-110). Hyderabad: ICFAI University Press.

Vårheim, A. (2009). Public libraries: Places creating social capital? Library Hi Tech, 27(3).

Vårheim, A., Audunson, R. A., \& Aabø, S. (2008). Folkebibliotekets bidrag til sosial integrasjon: Foreløpige funn fra PLACE-prosjektet. Nordisk Kulturpolitisk Tidsskrift, $11(1), 8-26$.

Vårheim, A., Steinmo, S., \& Ide, E. (2008). Do libraries matter? Public libraries and the creation of social capital. Journal of Documentation, 64(6), 877-892.

Wood, O. \& Landry, C. (2008). The intercultural city: Planning for diversity advantage. London: Earthscan.

Zweizig, D., \& Dervin, B. (1977). Public library use, users, uses: Advances in knowledge of the characteristics and needs of the adult clientele of American public libraries. In M.J. Voigt \& M.H. Harris (Eds.), Advances in Librarianship 7, (pp. 231-255). New York: Academic Press. 


\section{Table 1}

Use of the library as a meeting place: 750 respondents from three urban districts in Oslo were asked to tick off the different ways they've used the library as a meeting place.

\begin{tabular}{|c|c|c|}
\hline Can you remember that as a library user you have: & $\begin{array}{l}\text { Yes } \\
(\mathrm{N}=750)\end{array}$ & Percentage \\
\hline 1. Observed people with a different background & 293 & $39 \%$ \\
\hline 2. Accidentally met neighbors or friends & 240 & $32 \%$ \\
\hline 3. Got into conversations with strangers & 208 & $28 \%$ \\
\hline 4. Learned about organizations or activities in the local community & 189 & $25 \%$ \\
\hline $\begin{array}{l}\text { 5. Met with friends or colleagues to work on a common task or a leisure } \\
\text { activity }\end{array}$ & 157 & $21 \%$ \\
\hline 6. Used the Internet for social purposes, such as discussion groups & 125 & $17 \%$ \\
\hline 7. Learned about local matters or social issues that you are involved in & 117 & $16 \%$ \\
\hline 8. Participated in meetings such as author's nights, lectures, etc. & 107 & $14 \%$ \\
\hline $\begin{array}{l}\text { 9. Made appointments to meet family or friends in the library before } \\
\text { going to a movie, into the city, to shops, etc. }\end{array}$ & 78 & $10 \%$ \\
\hline
\end{tabular}


Table 2

Variable definitions

\begin{tabular}{|c|c|c|}
\hline $\begin{array}{l}\text { Independent } \\
\text { variables }\end{array}$ & Variable name & Description \\
\hline \multirow[t]{2}{*}{ (In block 1) } & $\begin{array}{l}\text { Urban district: } \\
\text { Multicultural } \\
\text { community }\end{array}$ & Respondents living in the multicultural community. \\
\hline & $\begin{array}{l}\text { Urban district: } \\
\text { Gentrified* } \\
\text { community }\end{array}$ & Respondents living in the gentrified community \\
\hline \multirow[t]{8}{*}{ (In block 2) } & $\begin{array}{l}\text { Occupation: } \\
\text { Working** }\end{array}$ & Main occupation is working \\
\hline & $\begin{array}{l}\text { Occupation: Job } \\
\text { seeker** }\end{array}$ & Main occupation is job seeking \\
\hline & $\begin{array}{l}\text { Occupation: } \\
\text { Homemaker }^{* *}\end{array}$ & Main occupation is being a homemaker \\
\hline & $\begin{array}{l}\text { Occupation: } \\
\text { Student }\end{array}$ & Main occupation is being a student. \\
\hline & $\begin{array}{l}\text { Age: } \\
\text { Old } \rightarrow \text { young }\end{array}$ & $\begin{array}{l}\text { Age registered in six age groups from old to young: } 70+, 60-69 \text {, } \\
50-59,40-49,30-39 \text {, and 18-29 }\end{array}$ \\
\hline & Education & $\begin{array}{l}\text { Registered at four levels from low to high education: primary and } \\
\text { secondary school, upper secondary school, university college or } \\
\text { university up to three years, and university college or university } \\
\text { more than three years }\end{array}$ \\
\hline & $\begin{array}{l}\text { Cultural linguistic } \\
\text { background }\end{array}$ & $\begin{array}{l}\text { Dichotomous variable, value } 0=\text { cultural and linguistic background } \\
\text { other than Norwegian, value } 1=\text { Norwegian cultural and linguistic } \\
\text { background }\end{array}$ \\
\hline & Household income & $\begin{array}{l}\text { Gross income coded in six groups: < NOK 100000 } \\
20000,202000-400000,401000-600000,601000-1 \text { mill., }>1 \text { mill. }\end{array}$ \\
\hline \multirow[t]{3}{*}{ (In block 3) } & $\begin{array}{l}\text { Participating in } \\
\text { local activities index }\end{array}$ & $\begin{array}{l}\text { Additive index showing the number of different local activities in } \\
\text { which respondents participate, scores from } 0-6\end{array}$ \\
\hline & $\begin{array}{l}\text { Improvement } \\
\text { activity index }\end{array}$ & $\begin{array}{l}\text { Additive index showing how active respondents have been to } \\
\text { improve local community conditions, scores from passive (value } 0 \text { ) } \\
\text { to very active (value } 6 \text { ) }\end{array}$ \\
\hline & $\begin{array}{l}\text { Community inst. } \\
\text { trust index }\end{array}$ & $\begin{array}{l}\text { Additive index showing respondents' trust in six community } \\
\text { institutions (community council, city council, Parliament, school, } \\
\text { police, public library), scores from distrust (value 0) to very high } \\
\text { trust (value 60) }\end{array}$ \\
\hline (In block 4) & Library use freq & $\begin{array}{l}\text { Frequency of use of the local library, coded as an 8-point scale } \\
\text { from } 0 \text { times last year up to } 40 \text { times or more }\end{array}$ \\
\hline
\end{tabular}

* Urban district is coded as dummy variables with middle class community as reference category

** Dummy variables for occupation with the variable occupation: retired as reference category

****100 NOK $=14$ USD in January 2009 
Table 2 continues

Variable definitions

\begin{tabular}{|l|l|l|}
\hline $\begin{array}{l}\text { Dependent } \\
\text { variables }\end{array}$ & Variable name & Description \\
\hline & Meeting intensity & $\begin{array}{l}\text { Use of different meeting types in the local library, scores from 0 to } \\
9, \text { index based on the questions in Table 1 }\end{array}$ \\
\hline & $\begin{array}{l}\text { Meeting type: } \\
\text { Square }\end{array}$ & $\begin{array}{l}\text { Use of the local library as a low-intensive meeting place, index } \\
\text { based on Table 2, questions 1-3, 9 }\end{array}$ \\
\hline $\begin{array}{l}\text { Meeting type: } \\
\text { Meet diff people }\end{array}$ & $\begin{array}{l}\text { Experienced encounters with people different from oneself in the } \\
\text { local library, index based on Table 1, question 1 }\end{array}$ \\
\hline & $\begin{array}{l}\text { Meeting type: } \\
\text { Public sphere }\end{array}$ & $\begin{array}{l}\text { Use of the local library as a public sphere, index based on Table 1, } \\
\text { question 7-8 }\end{array}$ \\
\hline & $\begin{array}{l}\text { Meint activities } \\
\text { Metamg type: }\end{array}$ & $\begin{array}{l}\text { Use of the local library as a high-intensive meeting place, index } \\
\text { based on Table 1, question 5 }\end{array}$ \\
\hline & $\begin{array}{l}\text { Use of the local library as a metameeting place, index based on } \\
\text { Table 1, question 4) }\end{array}$ \\
\hline & $\begin{array}{l}\text { Virtual meetings } \\
\text { Table 1, question 6 }\end{array}$ \\
\hline
\end{tabular}


Table 3

A linear regression analysis of the dependent variable meeting intensity

\begin{tabular}{|c|c|c|c|c|}
\hline \multirow{3}{*}{\multicolumn{2}{|c|}{ Independent variables }} & \multirow{4}{*}{$\begin{array}{c}\text { B coefficients } \\
\\
0.372 \\
(0.237)\end{array}$} & \multicolumn{2}{|c|}{ Collinearity statistics } \\
\hline & & & \multicolumn{2}{|c|}{ Tolerance VIF } \\
\hline & & & & \\
\hline \multirow[t]{2}{*}{ Block 1} & $\begin{array}{l}\text { Urban district: } \\
\text { Multicultural community }\end{array}$ & & 0.661 & 1.514 \\
\hline & $\begin{array}{l}\text { Urban district: } \\
\text { Gentrified community }\end{array}$ & $\begin{array}{c}0.684^{* * *} \\
(0.239)\end{array}$ & 0.641 & 1.561 \\
\hline \multirow[t]{8}{*}{ Block 2} & Occupation: Working & $\begin{array}{c}0.077 \\
(0.354)\end{array}$ & 0.371 & 2.696 \\
\hline & Occupation: Job seeking & $\begin{array}{c}0.442 \\
(0.782) \\
\end{array}$ & 0.809 & 1.236 \\
\hline & Occupation: Homemaker & $\begin{array}{c}0.365 \\
(0.850) \\
\end{array}$ & 0.781 & 1.280 \\
\hline & Occupation: Student & $\begin{array}{l}-0.215 \\
(0.560) \\
\end{array}$ & 0.472 & 2.120 \\
\hline & Age: Old $\rightarrow$ young & $\begin{array}{c}0.078 \\
(0.090)\end{array}$ & 0.545 & 1.834 \\
\hline & Education & $\begin{array}{l}-0.072 \\
(0.110)\end{array}$ & 0.784 & 1.275 \\
\hline & $\begin{array}{l}\text { Cultural linguistic } \\
\text { background }\end{array}$ & $\begin{array}{l}-0.743^{* *} \\
(0.286)\end{array}$ & 0.937 & 1.067 \\
\hline & Household income & $\begin{array}{l}-0.320^{* * * *} \\
(0.094)\end{array}$ & 0.720 & 1.388 \\
\hline \multirow[t]{3}{*}{ Block 3} & $\begin{array}{l}\text { Participating in local } \\
\text { activities index }\end{array}$ & $\begin{array}{l}0.402^{* * *} \\
(0.077)\end{array}$ & 0.841 & 1.189 \\
\hline & $\begin{array}{l}\text { Improvement activity } \\
\text { index }\end{array}$ & $\begin{array}{l}0.403^{\text {***** }} \\
(0.073)\end{array}$ & 0.829 & 1.206 \\
\hline & $\begin{array}{l}\text { Community inst. trust } \\
\text { index }\end{array}$ & $\begin{array}{c}0.012 \\
(0.011)\end{array}$ & 0.919 & 1.088 \\
\hline \multirow[t]{7}{*}{ Block 4} & Library use freq & $\begin{array}{l}0.359^{* * * *} \\
(0.048)\end{array}$ & 0.937 & 1.067 \\
\hline & (Constant) & $\begin{array}{l}1.462^{* * *} \\
(0.656)\end{array}$ & & \\
\hline & Adj. $R^{2}$ block 1 & 0.026 & & \\
\hline & Adj. R $^{2}$ block 2 & 0.035 & & \\
\hline & Adj. $\mathbf{R}^{2}$ block 3 & 0.212 & & \\
\hline & Adj. $R^{2}$ block 4 & 0.296 & & \\
\hline & Model sign & 0.000 & & \\
\hline
\end{tabular}

Standard errors are indicated in parentheses

*** denotes $1 \%$ significance level

** denotes $5 \%$ significance level

* denotes $10 \%$ significance level 
Table 4

Logistic regression analyses of six categories of meetings in the library

\begin{tabular}{|c|c|c|c|c|c|c|c|}
\hline & \multicolumn{6}{|c|}{$\begin{array}{c}\text { Meeting types } \\
\text { Dependent variables }\end{array}$} \\
\hline & $\begin{array}{l}\text { Independent } \\
\text { variables }\end{array}$ & Square & $\begin{array}{l}\text { Meet diff } \\
\text { people }\end{array}$ & $\begin{array}{l}\text { Public } \\
\text { sphere }\end{array}$ & $\begin{array}{l}\text { Joint } \\
\text { activities }\end{array}$ & $\begin{array}{l}\text { Meta- } \\
\text { meetings }\end{array}$ & $\begin{array}{l}\text { Virtual } \\
\text { meetings }\end{array}$ \\
\hline & (Constant) & $\begin{array}{l}-0.611 \\
(0.792)\end{array}$ & $\begin{array}{l}-0.632 \\
(0.729)\end{array}$ & $\begin{array}{l}-2.039^{* *} \\
(0.824)\end{array}$ & $\begin{array}{l}-2.037^{* *} \\
(0.924)\end{array}$ & $\begin{array}{l}-2.835^{* * *} \\
(0.801)\end{array}$ & $\begin{array}{l}-2.724^{* *} \\
(1.056)\end{array}$ \\
\hline \multirow[t]{2}{*}{ Block 1} & $\begin{array}{l}\text { Urban district: } \\
\text { Gentrified } \\
\text { community }\end{array}$ & $\begin{array}{l}0.228 \\
(0.282)\end{array}$ & $\begin{array}{l}0.536^{* *} \\
(0.268)\end{array}$ & $\begin{array}{l}0.183 \\
(0.284)\end{array}$ & $\begin{array}{l}-0.021 \\
(0.336)\end{array}$ & $\begin{array}{l}0.658^{* * *} \\
(0.285)\end{array}$ & $\begin{array}{l}0.642^{* *} \\
(0.357)\end{array}$ \\
\hline & $\begin{array}{l}\text { Urban district: } \\
\text { Multicultural } \\
\text { community }\end{array}$ & $\begin{array}{l}0.579^{\text {** }} \\
(0.291)\end{array}$ & $\begin{array}{l}1.039^{* * *} \\
(0.266)\end{array}$ & $\begin{array}{l}-0.270 \\
(0.288)\end{array}$ & $\begin{array}{l}-0.084 \\
(0.331)\end{array}$ & $\begin{array}{l}0.614^{\text {** }} \\
(0.281)\end{array}$ & $\begin{array}{l}-0.159 \\
(0.376)\end{array}$ \\
\hline \multirow[t]{8}{*}{ Block 2} & $\begin{array}{l}\text { Occupation: } \\
\text { Working }\end{array}$ & $\begin{array}{l}0.235 \\
(0.431)\end{array}$ & $\begin{array}{l}0.309 \\
(0.399)\end{array}$ & $\begin{array}{l}0.471 \\
(0.428)\end{array}$ & $\begin{array}{l}0.241 \\
(0.518)\end{array}$ & $\begin{array}{l}-0.325 \\
(0.412)\end{array}$ & $\begin{array}{l}0.885 \\
(0.637)\end{array}$ \\
\hline & $\begin{array}{l}\text { Occupation: } \\
\text { Job seeking }\end{array}$ & $\begin{array}{l}-0.772 \\
(-0.860)\end{array}$ & $\begin{array}{l}0, .201 \\
(0.838)\end{array}$ & $\begin{array}{l}0.412 \\
0.947)\end{array}$ & $\begin{array}{l}0.747 \\
(0.916)\end{array}$ & $\begin{array}{l}-0.691 \\
(0.926)\end{array}$ & $\begin{array}{l}2.050^{* *} \\
(0.983)\end{array}$ \\
\hline & $\begin{array}{l}\text { Occupation: } \\
\text { Homemaker }\end{array}$ & $\begin{array}{l}-0.161 \\
(-0.955)\end{array}$ & $\begin{array}{l}0.977 \\
(0.919)\end{array}$ & $\begin{array}{l}-0.059 \\
(1.209)\end{array}$ & $\begin{array}{l}1.140 \\
(1.044)\end{array}$ & $\begin{array}{l}0.422 \\
(0.931)\end{array}$ & $\begin{array}{l}2.658^{* * *} \\
(1.067)\end{array}$ \\
\hline & $\begin{array}{l}\text { Occupation: } \\
\text { Student }\end{array}$ & $\begin{array}{l}0.336 \\
(0.727)\end{array}$ & $\begin{array}{l}0.096 \\
(0.622)\end{array}$ & $\begin{array}{l}-0.312 \\
(0.721)\end{array}$ & $\begin{array}{l}1.123 \\
(0.714)\end{array}$ & $\begin{array}{l}-0.904 \\
(0.655)\end{array}$ & $\begin{array}{l}0.810 \\
(0.806)\end{array}$ \\
\hline & Age: Old $\rightarrow$ young & $\begin{array}{l}0.003 \\
(0.107)\end{array}$ & $\begin{array}{l}-0.090 \\
(0.101)\end{array}$ & $\begin{array}{l}-0.203^{*} \\
(0.109)\end{array}$ & $\begin{array}{l}0.391^{* * * *} \\
(0.129)\end{array}$ & $\begin{array}{l}0.009 \\
(0.106)\end{array}$ & $\begin{array}{l}0.390^{* * *} \\
(0.138)\end{array}$ \\
\hline & Education & $\begin{array}{l}-0.263^{*} \\
(0.135)\end{array}$ & $\begin{array}{l}-0.101 \\
(0.122)\end{array}$ & $\begin{array}{l}0.043 \\
(0.135)\end{array}$ & $\begin{array}{l}-0.281^{*} \\
(0.147)\end{array}$ & $\begin{array}{l}0.099 \\
(0.129)\end{array}$ & $\begin{array}{l}-0.020 \\
(0.161)\end{array}$ \\
\hline & $\begin{array}{l}\text { Cultural linguistic } \\
\text { background }\end{array}$ & $\begin{array}{l}-0.855^{\text {** }} \\
(0.381)\end{array}$ & $\begin{array}{l}-0.328 \\
(0.323)\end{array}$ & $\begin{array}{l}-0.069 \\
(0.352)\end{array}$ & $\begin{array}{l}-0.782^{* * *} \\
(0.345)\end{array}$ & $\begin{array}{l}-0.025 \\
(0.340)\end{array}$ & $\begin{array}{l}-0.984^{* *} \\
(0.362)\end{array}$ \\
\hline & Household income & $\begin{array}{l}-0.137 \\
(0.118)\end{array}$ & $\begin{array}{l}-0.019 \\
(0.106)\end{array}$ & $\begin{array}{l}-0.250^{* * *} \\
(0.115)\end{array}$ & $\begin{array}{l}-0.334^{* * *} \\
(0.124)\end{array}$ & $\begin{array}{l}-0.125 \\
(0.111)\end{array}$ & $\begin{array}{l}-0.376^{* * * *} \\
(0.030)\end{array}$ \\
\hline \multirow[t]{3}{*}{ Block 3} & $\begin{array}{l}\text { Participating in } \\
\text { local activities index }\end{array}$ & $\begin{array}{l}0.251^{\text {*** }} \\
(0.098)\end{array}$ & $\begin{array}{l}0.249^{* * * *} \\
(0.087)\end{array}$ & $\begin{array}{l}0.205^{* *} \\
(0.090)\end{array}$ & $\begin{array}{l}0.320^{* * * *} \\
(0.102)\end{array}$ & $\begin{array}{l}0.250^{* *} \\
(0.089)\end{array}$ & $\begin{array}{l}0.278^{* *} \\
(0.110)\end{array}$ \\
\hline & $\begin{array}{l}\text { Improvement } \\
\text { activity index }\end{array}$ & $\begin{array}{l}0353^{* * * *} \\
(0.100)\end{array}$ & $\begin{array}{l}0.080 \\
(0.082)\end{array}$ & $\begin{array}{l}0.294^{\text {***k }} \\
(0.085)\end{array}$ & $\begin{array}{l}0.230^{* *} \\
(0.093)\end{array}$ & $\begin{array}{l}0.136^{*} \\
(0.082)\end{array}$ & $\begin{array}{l}0.298^{* * * *} \\
(0.099)\end{array}$ \\
\hline & $\begin{array}{l}\text { Community } \\
\text { inst. trust index }\end{array}$ & $\begin{array}{l}0.031^{* *} \\
(0.014)\end{array}$ & $\begin{array}{l}-0.007 \\
(0.012)\end{array}$ & $\begin{array}{l}0.029 \\
(0.014)^{* *}\end{array}$ & $\begin{array}{l}0.021 \\
(0.015\end{array}$ & $\begin{array}{l}0.018 \\
(0.013)\end{array}$ & $\begin{array}{l}-0.001 \\
(0.016)\end{array}$ \\
\hline \multirow[t]{7}{*}{ Block 4} & Library use freq & $\begin{array}{l}0.432^{\text {**** }} \\
(0.077)\end{array}$ & $\begin{array}{l}0.360^{* * *} \\
(0.059)\end{array}$ & $\begin{array}{l}0.215^{* * *} \\
(0.026)\end{array}$ & $\begin{array}{l}0.008 \\
(0.065)\end{array}$ & $\begin{array}{l}0.303^{\text {**** }} \\
(0.056)\end{array}$ & $\begin{array}{l}0.007 \\
(0.069)\end{array}$ \\
\hline & Nagelkerke $R^{2}$, bl.1 & 0.027 & 0.061 & 0.005 & 0.007 & 0.025 & 0.037 \\
\hline & Nagelkerke $R^{2}$, bl.2 & 0.053 & 0.072 & 0.046 & 0.141 & 0.049 & 0.167 \\
\hline & Nagelkerke $\mathbf{R}^{2}$, bl.3 & 0.178 & 0.123 & 0.155 & 0.216 & 0.118 & 0.234 \\
\hline & Nagelkerke $R^{2}$, bl.4 & 0.277 & 0.228 & 0.195 & 0.216 & 0.200 & 0.235 \\
\hline & $\begin{array}{l}\text { Omnibus tests of } \\
\text { model coefficients, } \\
\text { full model }\end{array}$ & $\begin{array}{l}\chi^{2}=104.03 \\
d f=14 \\
p<0.005\end{array}$ & $\begin{array}{l}\chi^{2}=87.657 \\
d f=14 \\
p<0.005\end{array}$ & $\begin{array}{l}\chi^{2}=68.895 \\
d f=14 \\
p<0.005\end{array}$ & $\begin{array}{l}\chi^{2}=69.594 \\
d f=14 \\
p<0.005\end{array}$ & $\begin{array}{l}\chi^{2}=73.199 \\
d f=14 \\
p<0.005\end{array}$ & $\begin{array}{l}\chi^{2}=71.570 \\
d f=14 \\
p<0.005\end{array}$ \\
\hline & $\begin{array}{l}\text { Percentage of cases } \\
\text { correctly classified }\end{array}$ & 73.7 & 66.9 & 74.1 & 81.6 & 70.9 & 82.5 \\
\hline
\end{tabular}

Standard errors are indicated in parentheses

$* * *$ denotes $1 \%$ significance level

$* *$ denotes $5 \%$ significance level

$*$ denotes $10 \%$ significance level 
$1 \quad \mathrm{R}^{2}$ is the coefficient of determination, which displays the proportion of variability in our data set that is accounted for by each statistical model. Adjusted $\mathrm{R}^{2}$ is a modification of $\mathrm{R}^{2}$ that adjusts for the number of explanatory factors in a model. Unlike $\mathrm{R}^{2}$, the adjusted $\mathrm{R}^{2}$ increases only if the new independent variable improves the model more than would be expected by chance.

ii The library use frequency was divided into: $0,1-2,3-5,6-9,10-19,20-29,30-39,40$ times or more visits to the library last year.

3 Multicollinearity occurs when two or more of the independent variables are highly correlated and the effect of some variables might be underestimated.

$4 \quad$ The collinearity diagnostics function in SPSS was used, giving two values, tolerance and VIF (Variance inflation factor). Tolerance indicates how much of each independent variable that is not explained by the other independent variables in the model (Pallant, 2007). If this value is very small, less than 0.2, it indicates that the multiple correlations with other variables is high and, thus, suggests the possibility of multicollinearity. All the independent variables included in the analyses scored higher than 0.2 on the diagnostic measure of tolerance. The VIF value is the inverse of the tolerance value. VIF is an index measuring how much the variance of a coefficient is increased because of collinearity. Typically a VIF value greater than 10 is of concern. Our explanatory factors had all clearly lower VIF values.

5 There is a positive and medium strong relationship between the explanatory factor library use frequency (library use freq) and the dependent variable meeting intensity, investigated using the Pearson productmoment correlation coefficient $(r=0.37, n=569, p<0.0005)$.

6 The meeting types square $\left(\chi^{2}=104.03, \mathrm{df}=14, \mathrm{p}<0.005\right)$, meet diff people $\left(\chi^{2}=87.657, \mathrm{df}=14, \mathrm{p}<0.005\right)$, public sphere $\left(\chi^{2}=68.895, \mathrm{df}=14, \mathrm{p}<0.005,\left(\chi^{2}=69.594, \mathrm{df}=14, \mathrm{p}<0.005\right)\right.$, metameetings $\left(\chi^{2}=73.199\right.$, $\mathrm{df}=14, \mathrm{p}<0.005)$, and virtual meetings $\left(\chi^{2}=71.570, \mathrm{df}=14, \mathrm{p}<0.005\right)$, see table 4 . 